\title{
CHINESE AND MALAY INTERACTION IN WEST KALIMANTAN: DISCOVERING HARMONY IN DIVERSITY OF ETHNIC GROUPS THROUGH LOCAL WISDOM
}

\author{
DWI SURYA ATMAJA AND \\ M. EDI KURNANTO* \\ Institut Agama Islam Negeri Pontianak
}

\section{Abstract}

This research aims to explore the wisdom of socio-religious interaction and tradition in West Kalimantan Malay society towards Chinese ethnic. This research recommends local wisdom as a media to downgrade the tension of social political and religious interactions that have been perceived recently as the threat of national and even global harmony. The source of data in this study was Deutro Malay ethnic and Chinese ethnic at Teluk Pak Kedai. The data was determined through purposive techniques by considering the two circles of key informants, i.e. information from the closest circumference (epicentrum) with the source of wisdom, which in this study consists of a closed circle from the figure of Haji Ismail Mundu and Foundation (China), and information from peripherals. The Data collected through in-depth interviews, observations and documentation were then analyzed by using qualitative normative cycle formats to be presented in thematic classifications in line with the focus and research questions. This study concluded that the theological characteristics of Haji Ismail Mundu can easily adjust to the characteristics of the Chinese. The harmonious reciprocity between the two traditions, in terms of the inter-ethnic reciprocal relationship manifested in the Teluk Pak Kedai, is unique

\footnotetext{
* Corresponding author: M. Edi Kurnanto, Jl. Letjend Suprapto, Benua Melayu Darat, Pontianak, West Kalimantan, Indonesia 78113. E-mail: kurnantoedi@yahoo.co.id
} 
as seen in the respect and appreciation given by the Confucian Chinese in the form of displaying a photo of Haji Ismail Mundu in the Phe Kong worshiping in homes. Every potential of conflict has always been successfully overcome by "intensity" and "modesty" through the figure of Haji Ismail Mundu and being committed to preserve his heritage.

Penelitian ini bertujuan untuk mengeksplorasi kearifan interaksi sosial keagamaan dan tradisi masyarakat Melayu Kalimantan Barat terhadap etnis Tionghoa. Penelitian ini merekomendasikan kebijakan untuk menurunkan ketegangan interaksi sosial politik dan keagamaan yang baru-baru ini dianggap sebagai ancaman keharmonisan nasional dan bahkan global. Sumber data dalam penelitian ini terdiri dari entitas etnis Melayu Deutro dan etnis Cina di Teluk Pak Kedai. Data ditentukan melalui teknik purposif, yaitu dengan mempertimbangkan dua lingkaran informan kunci; lingkar terdekat (epicentrum) dengan sumber kebijaksanaan yang dalam penelitian ini terdiri dari lingkaran tertutup dari sosok Haji Ismail Mundu dan Yayasan (Cina), dan informasi kunci dari periferal. Data dikumpulkan melalui wawancara mendalam, observasi dan dokumentasi, kemudian dianalisis dengan menggunakan format siklus normatif kualitatif untuk disajikan dalam klasifikasi tematik sesuai dengan fokus dan pertanyaan penelitian. Penelitian ini menyimpulkan bahwa karakteristik teologis Haji Ismail Mundu, dapat dengan mudah menyesuaikan dengan karakteristik orang Cina. Itu adalah hubungan timbal balik yang sangat harmonis dalam hal relasi antar etnis yang dimanifestasikan di Teluk Pak Kedai sehingga ditemukan suatu fenomena unik, yaitu rasa hormat dan penghargaan dari orang Cina Konfusianis dalam bentuk memajang foto Haji Ismail Mundu di tempat ibadah (Phe Kong) yang dibangun di rumah-rumah mereka. Setiap potensi konflik yang muncul selalu berhasil diatasi dengan "kedekatan" dan "kesederhanaan" melalui peran seorang figur Haji Ismail Mundu dan komitmen menjaga warisan tradisinya.

Keywords: Chinese Malay interaction; inter-ethnic conflicts; local wisdom; socio-religious harmony; tolerance tradition. 


\section{Introduction}

The interaction between Chinese and Malay in the Malay populated country like Indonesia is always interesting to study. It is so because relation between these two ethnics is usually full of suspicion. Chinese-Indigenous Malay relation is usually seen as only harmonious on the surface but has a thousand turmoil within. This assumption usually rises since a Chinese-Indigenous relation has a different terminology of "jokes". If an indigenous Malay person dies, people will say: innā lillāh wa innā ilaih rā$j i$ i $\bar{u}$, there is news that the Fulan just died. But this is not the case when there is person of Chinese died.

In addition, for the context of West Kalimantan, the interaction of Chinese-Malay, our history seems to present a conflicting scene. Unfortunately, the historical reality of West $\mathrm{Ka}$ limantan cannot be separated from the history of conflict and violence between ethnic/racial groups, including conflicts that involved Chinese. Supriyadi (2008) from the Dayak Academy (the Institute of Dayakology) stated that since the $18^{\text {th }}$ century there had been inter-ethnic conflicts when the Sambas and Mempawah Kingdoms brought mining workers from Chinese ethnic. The conflict of the Chinese versus the Dayak was also recorded as the Red Bowl event in October-December 1967. The phrase "history repeated" (history is back) flies in and burdens the researcher's image (Brandell 1949).

When the imagination spread to the national scale, Ambon conflict between indigenous people and Sulawesi migrants, Sumbawa conflict, Bali, May 1998 Jakarta, the tragedy of Sampit was soon interwoven and tangled; and when the time returned to its current context, the researcher was immediately caught up in the controversial case of Jakarta Governor Ahok who was accused of doing religion defamation (the case of al-Maidah: 51 in the Thousand Islands) which had implications for recent high 
political social tensions ${ }^{2}$. Then, when the discourse develops into the issue of the Jakarta bay reclamation ${ }^{3}$ (Suara Jakarta 2015; Omar 2017), the potential for indigenous and non-indigenous (Chinese) conflicts is increasingly alarming (Maksum 2016; Susilo 2015). Reflection on the history of conflict extends the spectrum of observations to economic and political dimensions in addition to religious and social ones. When this was extended to a global scale, tensions between indigenous people and migrants also come up into surface.

The general view that the Chinese-Malay interaction relationship is only harmonious on the surface and the history of conflicts involving Chinese-Malay does not apply in Teluk Pak Kedai district. Chinese-Malay relations in Pak Kedai are indeed in peace without conflicts. When viewed from the side of the interaction between layers of age of people, they look very united. Everyday children blend as if they are not from a different ethnicity. They play with intimacy, even visit each other, and eat together in the host's kitchen. All of which symbolizes how their interaction has no ethnic dividers. Likewise with adults, their social interactions, even in the economic and political context of the village, are neither hindered by ethnic differences. There are ethnic Malays who work for Chinese people. On the contrary, there are not a few Chinese who work for Malays (Purcel 1981).

Harmonious Chinese-Malay interaction in Teluk Pak Kedai without a record of conflicts prides Indonesia on and stimulates the interest of researcher to explore and to reveal the basis of its construction to create a conceptual foundation in formulating

${ }^{2}$ The history of demonstration in Indonesia has recorded its high level. Million citizens have participated in Aksi Bela Islam 212 Gerakan Nasional Pengawal Fatwa Majelis Ulama Indonesia (GNPF-MUI) so that President, vice President, ministers had to approach the people persuasively by joining them in rain at Monas Jakarta.

${ }^{3}$ Moreover there is an issue that such reclamation project is the big project of China to make Indonesia obedient under Singapore policy/power 
policies that are culturally persuasive. This is to strengthen the social order to the Unity in Diversity of the Republic of Indonesia (NKRI), which today reveals emerging vulnerabilities.

In the political economy perspective, Indonesia has actually been dominated by Chinese ethnicity (Non-Indigenous Indonesian Citizens) (Adidharta 2013). This phenomenon of socio-economic disparity increasingly alarms with the symptoms of aggressive expansion of the People's Republic of China through the disputes over territorial boundaries (including the EEZ-Exclusive Economic Zone) with Southeast Asian countries and the South China Sea; the news about the maneuvering of Chinese warships in the Natuna Sea has activated national preparedness. West Kalimantan, on the other hand, is known as the following terms: City of Thousand Vihara, Barongsai, Tatung, Mie Tiaw, Chinese Pontianak, Amoy Singkawang, Mayor of China, Deputy Governor of China, Sinshe and various Chinese cultural, social, and political indicators others. This phenomenon if not well addressed will be a time bombing that can explode at any time (Poerwanto 2005).

This research is intended to search for the science of "bomb disposal" by adopting the wisdom of the Teluk Pak Kedai community in shaping an almost perfect Chinese-Malay interaction. This study aims to uncover the social and theological recipes existing there, so that the recipes can be used for making Chinese-Malay interactions harmonious in Indonesia, even in the context of interactions between all ethnic groups in Indonesia. For such purpose, this research is focused on finding out the formula of tolerance across races, ethnicities and religions which had been integrated into life at the Teluk Pak Kedai community, especially regarding the traditions of Chinese-Malay interaction in Teluk Pak Kedai and arguments of tolerance and of confrontation (tolerance limits) which underlie such interaction (Vasanty 1999). 
In accordance with the formulated problem, this study aims to describe the dynamics of interaction between Chinese and Malays in Teluk Pak Kedai district, Kubu Raya regency, West Kalimantan. For that purpose, the researcher used a qualitative approach. The use of this qualitative approach was based on the following considerations: (1) The characteristics of dynamic qualitative research are in line with the interrelated dynamics of theory and social reality that tend to be intertwined. Therefore, flexibility and necessity of inter-movement of hypotheses, thesis, anti-thesis, and synthesis relations are needed. The analysis was carried out together with data collection. (2) A qualitative approach was also needed in order to explore deeply and broadly so that the strict limits of variables in the quantitative approach tend to inhibit. (3) This study anticipates to reveal phenomena that are natural and grounded. (4) The aspects researched can be studied in depth, thorough, detailed and personal.

This research was conducted in Teluk Pak Kedai district, Kubu Raya, West Kalimantan. The selection of this setting was done by considering that the area is unique in terms of portraying Chinese and Malay interactions. Its uniqueness in this connection is interpreted as a relationship different from other regions since the interaction in this area has been established for a long time, there have never been any problems between the two ethnic groups.

The subject of the research were focused on the dynamics of inter-ethnic interaction (Chinese-Malay), such as forms of cooperation, association, tradition, social boundaries, tolerance, cultural symbols, traditions, and other cultural instruments inherent in the traditional wisdom of the social diversity of the district Teluk Pak Kedai, regency of Kubu Raya, West Kalimantan.

The data in this study were collected using three data collection techniques, i.e., interview, observation, and documentation. 
Furthermore, the data were analyzed by using the interactive data analysis techniques of Miles and Huberman models, namely data reduction, data display and verification, and conclusion drawing. To guarantee the validity of the data, the data was then checked by using triangulation and member check.

\section{Interaction of Chinese and Malay Bugis in the Teluk Pak Kedai}

\section{China in the Teluk Pak Kedai}

Chinese is one of the ethnic groups which has a long history in West Kalimantan, especially in Teluk Pak Kedai district, Kubu Raya regency. Until now, the Chinese people could be a generation of Chinese immigrants who entered Indonesia in the form of small groups in the past, originating from or consisting of several ethnic groups from two provinces in China, namely: Fukien and Kwangtung Province.

The Chinese immigrants inhabited the region approximately from the $16^{\text {th }}$ century to the end of the $19^{\text {th }}$ century. Hokkien immigrants that originate from Fukkien Province in southern China are classified as good at trading. They are verily widespread in Indonesia, especially in Eastern Indonesia, East Java, Central Java, and also the West Coast of Sumatra. Other immigrants are Teo Chiu ethnicity. This ethnicity originates from the southern coast of China, inland in the Swatow in the eastern part of Kwangtung Province. The Chinese people from this ethnicity and Hakka ethnicity (Khek) are known as mining labors in East Sumatra and Biliton (Belitung). Even though Hakka ethnicity is ethnicity in China that migrate a lot, this ethnicity is not classified as maritime ethnicity. However, due to the condition of their barren areas and relatively poor livelihoods, they were hired together-Khek and Teo Chiu-and were employed by companies for exploring mineral resources, such as; gold and tin, and other mining items (Alqadrie 1990). 
The background of their migration makes Chinese in Indonesia live well in West Kalimantan, especially in the Teluk Pak Kedai, Kubu Raya regency. The Chinese people in their lives always move in various sectors of the economy, starting as farmers, fishermen, and traders. Their lifestyles in such area are somewhat unlike other Chinese ethnicities which can be considered exclusive. The Chinese ethnicity in the Teluk Pak Kedai is based on information received from various informant circles (epicenter and peripheral), especially based on ethnic versions of Bugis in Teluk Pak Kedai.

Their lives, although they are still considered to uphold the traditions and culture of the ancestors, especially in the spiritual life, have been integrated with the traditions and culture of the local culture, especially the culture of Bugis ethnic. Customs with the nuances of their ancestors' habits can still be seen from their daily lives. The red color is still a feature of the Chinese settlements, as well as Toapekong (shrine) remain a ritual instrument that is intentionally placed specifically on the side of the living room. Toapekong almost exists in every Chinese house in Teluk Pak Kedai. It is in line with the functional approach since Confucian Chinese always pray before going out looking for sustenance. It is not only functional in terms of theological beliefs but also in a sociological order that is based on religious heterogeneity. In other places, this shrine is commonly found outside the home, on the side of the door.

Religiosity that lives and is embraced by the Chinese communities is more oriented towards ancestral traditions and culture, namely: Confucianism and Taoism. They never abandon their traditions and systems of ancestral beliefs in the Teluk Pak Kedai such as Chinese new year, cap go meh, grave prayer, birth, death, and others.

Rasmi Sattar (the former Head of the Regional Office of the Ministry of Religion of West Kalimantan) and his Grandfather 
(Ambo 'Lala), who inherently have served as Ponggawa (Village Chief Coordinator) as informants as well as community leaders in Teluk Pak Kedai, states that the Chinese people persistently hold their culture and beliefs of his ancestors. Yet, at the same time, they are also integrated with the values, traditions and local culture (Lyman 1968).

\section{Malay Bugis in The Teluk Pak Kedai}

The existence of Bugis ethnicity in the Teluk Pak Kedai originated from the arrival of four brothers and at the same time had been the personal guard of Sultan Hasanuddin in Makassar, namely: Ade Kecua, Ade Jerutsung, Ade Kepung, and Ade Rempeng. It is said that when the four brothers arrived at "zero point" of the bay-the coastal coast of Teluk Pak Kedai. Before being named with Teluk Pak Kedai, this area was called Telo 'Penyengat for when the four brothers' boats docked, there were many stingers, family of bees. When the nest is taken, lots of eggs are scattered and bee honey from the nest is taken. Based on the sweet taste of honey, it is believed that it will bring prosperity in the future. Shortly thereafter the Chinese came by opening a shop. The Chinese shop on the river bank then was named Cik Kedai. The name 'Cik' was shifted to 'Pak', so that it became Pak Kedai. Teluk Pak Kedai has historically not only geographically formed a bay, because it is more deltaic, and more directed to the historical aspects of the arrival of Bugis and Chinese in the region. This was seen as the beginning of the establishment of the simplicity of interaction between Bugis and Chinese in the Gulf of Pak Kedai region.

When viewed from the socio-cultural aspects and their identification, Bugis people in the region-as the majority population-are part of the Malay family. They are not limited to Malays living in West Kalimantan, as well as Indonesia, but also those Malays in several countries, especially in Southeast Asia, 
such as in the Peninsula of Malaysia, Brunei, Thailand, Singapore and the Philippines (Austronesia) ${ }^{4}$. Although Malay and Bugis are even separated in several subgroups, but linguists and those who are expert in culture always consider them as one family. Malay land covers a large area and its people represent the entire great nation in the world. The Malays have stood as a distinct nation thousands of years ago. The proof of their existence, from the oldest ancient relics, can be observed from the human and animal skeletons and stone-age stone axes. Such materials are prehistoric objects dated from the Mesolithic and Neolithic periods (Ali 1985, 5-7). To the context of West Kalimantan people, all Bugis are Malays but not vice verse. There are local Malays such as Sambas Malay, Pontianak Malay, etc.; and Bugis are Malays whose ancestors are from South Sulawesi (Brandell 1949).

The Bugis community in the region as a whole are Muslim. In the Teluk Pak Kedai area, Bugis are synonymous with Muslims and generally settle on the coast of rivers and beaches. Although there are Christianity, Hinduism, Buddhism and Confucianism in, the influence of Islam remains large in coloring social lives. The influence of Islam brought by Bugis nomads in this region has been ingrained. The interaction of Bugis with other ethnicities is factually full of modesty. There has never been any dispute within families or environments regarding the problems of their lives, both socially, economically, culturally and religiously. This proves that the Bugis people hold firm on their Islamic beliefs

${ }^{4}$ Although Malay and Bugis are even separated in several subgroups, but linguists and those who are expert in culture always consider them as one family. Malay land covers a large area and its people represent the entire great nation in the world. The Malays have stood as a distinct nation thousands of years ago. The proof of their existence, from the oldest ancient relics, can be observed from the human and animal skeletons and stone-age stone axes. Such materials are prehistoric objects dated from the Mesolithic and Neolithic periods 
and raise empathy from other ethnic groups in the village (Arnold 1995).

The ability of Bugis people to building an atmosphere of coexistence, and of Chinese ethnicity, further confirms that Bugis in the region are tolerant and open. They have accepted ethnic others as part of their own lives. The pattern or order of life of Chinese, which is considered by the Bugis as full of modesty makes the Bugis accustomed to the conditions adjusted with Chinese people. Each ethnic group-Bugis and Chinese-do not feel disturbed, suppressed or controlled. The values of customs, language, and culture, can still survive and color their lives. In summary, Bugis ethnicity considers that their life together with Chinese goes on harmoniously and peacefully, lives side by side, and needs each other (Jackson 1970).

The characteristics of Bugis people in the bay, which are interesting points to strengthen the view of ethnic Bugis, are strongly nuanced with religious views that underlie their social attitudes. Viewed from the religious aspect, the Bugis community in the area is one of the Sunni followers, namely the Shafi' $i$ School, especially in matter of fiqh (Islamic jurisprudence), one of the schools that is widely adopted and developed in Indonesia. More specifically, the Bugis people in the Teluk Pak Kedai community are the followers of the Naqshabandiyah Sufi Order, which refers to Islamic teachings that have been internalized for a long time by a Mufti of the Kingdom of Kubu, namely Guru Haji Ismail Mundu. The internalization of Islamic teachings in the actualization of social life has also realized sense of tolerance from the people. Every traditional treasure, such as; wedding ceremonies as well as village social arrangements that involve the democratization of the village are always based on tolerance to live together wisely (Bruneissen 1992).

The internalization of social values in living together that had been instilled for a long time by Haji Ismail Mundu led him 
and his followers to maintain the tradition of Sufism, especially followers of the Naqshabandiyah Sufi Order. This Sufi Order is part and parcel of the religious lives of community leaders and society in the Pak Kedai Village. ${ }^{5}$ The other characteristic of Bugis ethnicity in this area is strongly influenced by their religious belief, namely Islam as a source of their beliefs. Knowledge of the interactions of each ethnic group is introduced from understanding religion while maintaining the teachings of Haji Ismail Mundu (Riyadhi 2011).

Islamic Sharia has laid down the basic principles of social life to live in harmony and balance (Alqadrie 1987). The principles of life in Teluk Pak Kedai, which are based on Islamic social interactions, further complement the belief of the people. They are convinced that whatever their livelihoods are, as farmers, fishermen and other livelihoods, have to always get the blessing of Allah swt. That is in accordance with some informants who at all times embrace firmly such belief as demonstrated by their figure i.e., Haji Ismail Mundu.

The Chinese people in the bay, as long as this observation and research were carried out, interact with the Bugis ethnicity harmoniously and modestly. During the day, they are busy working, but in the evenings their social atmosphere of life is quite intimate by talking each other casually. The interaction of Chinese ethnicity in the bay rarely takes place in the streets chitchats. Yet it is more planned, such as; making arrangements for

${ }^{5}$ This Naqshabandiyah sufi order has been known to the public since it was taught by Guru Haji Ismail Mundu. It is practiced not only by Bugis Malays in the Pak Kedai bay village, but also by ethnic Chinese who existed without changing their beliefs as Confucian followers. His experience was aimed solely at getting closer to the core of science or "essence". It is practiced for social life together, such as; tolerance and equality face life's difficulties—such as; treat sick people-based on religious suggestions, or Islamic teachings. Interview with Taufik, community leader in the Pak Kedai Bay village, Kubu Raya Regency, West Kalimantan. 
casual talk in stalls or cafes, even in homes. This indicates that the Chinese are always able to put themselves in their portion. When they are working, they really wrestle the world of work, but during the holidays they indeed enjoy their relaxed time.

\section{Tolerance Tradition of Chinese-Bugis Interaction in the Teluk Pak Kedai}

It is slightly not difficult to distinguish physically between people from Chinese and Bugis people in the bay, especially from the color of the skin and the shape of their eyes. There are no reliable sources so far about when exactly Chinese people entered the bay. Information from various informants indicates that the entry of Chinese in the region had passed five generations or around 350 years along with the spread of Chinese people in West Kalimantan.

The open and tolerant attitudes of Bugis folks for Chinese immigration make their lives modest. Chinese as well as Bugis ethnicity, and other ethnicities, such as Malay, Arabic, and Madura in Teluk Pak Kedai, work as farmers, fishermen, breeders, traders and so on. Uniquely, the profession of traders and collectors does not indicate any ethnic dominance. Between Chinese and Bugis merchants, there is cooperation, mutual assistance, and even mutual debt. Among these ethnicities, a good assimilation relationship has been established. The easy-to-find assimilation program is a mixed-marriage between several Chinese and Bugis ethnic groups.

Understanding of the relationship in the context of social interaction between Chinese and Bugis in the Teluk Pak Kedai with long-standing regional, social and economic conditions has been along with the development and progress of the era. On that basis, religious differences are not troubling factors that hinder integration in inter-ethnic community life in the place. The interwoven inter-ethnic social cooperation has been going 
on for a long time, either in traditional, ritual celebrations or national ones. This implies a mixture in the dimension of collective life. There are several factors taken in to account as strengthening the fabric of social interaction between Chinese and Bugis ethnicities in the Teluk Pak Kedai include:

\section{The Highly Respected Religious and Social Values}

The social harmony in the Teluk Pak Kedai with its various dimensions is much influenced by the existence and form of leadership that is able to bring together and harmonize between strong and weak groups. The strong leadership with full of modesty is the main factor in dissolving social bargaining so that the dominance of the strong element in the economic, political, social and religious dimensions will transform into the strong guardianship of the weak one. At this very point, the strong will think that his strength is a mandate and gift that they must use to protect and help the weak. Besides, there will be a sense of affection and affinity in living together. This reminds us of the human nature with their two functional dimensions: the servant of God and the vicegerent of God. ${ }^{6}$

God creates differences in human abilities in order to function those strong folks able to be guards for protecting, assisting, leading and relinquishing the pains and sufferings of the weak, needy ones. Such strengths are God's trustworthiness and mandate toward them. There is a close connection between two words amānah (mandate) and imān (faith). Any strength possessed by a person or group of people, or society or ethnicity, cannot be seen merely as a divine gift but must also be seen as an

\footnotetext{
${ }^{6}$ Strong man is intended to have more content in the field of faith, intelligence, skills, wealth, position and power. Whereas the weak group or $d u^{\prime} a f a$ ', i.e., humans who are weak in various aspects of life can be physically weak, do not get good luck in terms of work and fulfill economic needs, or are experiencing things injustice in life, such as; debt-ridden, living with poverty, or living in the pressure of other people's power.
} 
obligation as the test of faith. This is as confirmed in the Quran, Surah al-An'ām verse 165, Surah al-Kahf verses 7-8, and with regard to that as well as Surah al-Zukhruf verse 32, "Why did they give away the mercy of your God? We have determined between them in the life of the world. And we have increased some of them above others. And your Lord's mercy is better than what they collect".

Enlivening life each other has colored over ethnic life despite their diversity in the Teluk Pak Kedai. Its actualization is performed through doing their human obligation without ignoring rules of a family basis as recommended by the Prophet Muhammad saw. In line with that demand, those who do not inculcate compassion in social interaction in this region can be equated with the position of those who are not faithful in God. On the contrary, people who work and strive for progress and sustainability of living together will get a reward that is more than just doing prayer, fasting and giving alms.

Islamic teachings greatly dominate the interaction of religious and social life in that region. The inter-ethnic life is based on a collective attitude of life-derived from beliefs. There are teachings that originate from the religion they adhere to, and that are based on old customs or certain social and ideological ideals all of which influence the actions and collective behaviors in their daily lives, including in the economic activities of the community. Interrelationships between ethnic groups in the Teluk Pak Kedai, which are considered agrarian, go on a calm and modest atmosphere filled with traditions, long customs and from generations to generations. Communities are loyal to the ways and rhythms of what they have inherited from their ancestors.

Islamic leadership voices up that the Islamic teachings are divine revelations which to some extent also "revive the soul" 
and give impetus to the development of spiritual and physical life, for the benefit of individuals and society. That is the progress of human life lies in the balance between the progress of spiritual and physical life.

The only weakness of the community living in the Teluk Pak Kedai is the lack of skilled young people who are intelligent, dynamic, and in love with their territory and society. Such young people generally leave the area and move to (an)other region(s) such as Pontianak City. Such young people in the community are expected to contribute to building humanity and civilization in the region, especially in facilitating their social leadership. The weakness is not due to the lack of aspects of internalization but lies in the way and content-material-given in the internalization process that should prioritize the interests and development of the region of Pak Kedai. As the result, life in Teluk Pak Kedai tends to be static "peaceful" and remains lonely for young, fresh workers, and they should be able to become motors of development while creating qualified leadership (Harvey 1974).

\section{Mutual Need within the Inter-Ethnic Life}

Community life in the Teluk Pak Kedai region is plural and integrated. Being integrated means that the community has rich and diverse cultures on the one hand. On the other hand, it builds inter-ethnic interactions that continue to foster despite the different customs and cultural values embraced by each ethnic group.

In the Teluk Pak Kedai area, the people are of different ancestry, race, and culture. This difference has implications for the need to get to know each other, so that the social interactions keep continued peacefully, are free from social jealousy and then give birth to mutual trust as it can be observed today.

Factually, the social interaction built peacefully in the Teluk Pak Kedai is the key of social life. The physical meeting of per- 
son in the community physically will result in a good social interaction. Such social interaction will only occur if people in the community with the same or different ethnic groups work together, communicate with each other and so on. Collaboration and cooperation rise when every interacting person realizes that they have the same interests, and they at the same time have proper knowledge and control of themselves as important as facts in doing the collaboration and cooperation.

\section{Self-Restraint Ability from Each Ethnic Group}

Social facts in the region of Pak Kedai show a collective effort to guide, protect, defend and enhance the rights and dignity together. The most dominant indicator held by all ethnic groups in the Teluk Pak Kedai (Chinese, Bugis, and Madura) is the ability to hold back. They are able to refrain from encouraging individualism and ethnocentrism. They live, work and solve problems together. Uniquely, the joint effort is manifested in the reality of "modesty", that is a wonderful reality. if decomposed, it will turn out to have a high complexity. Therefore, this reality is called "wisdom".

Some of the abilities in working on the human sector can be seen in the phenomenon of maintaining the principle of kinship and mutual cooperation, as the capital of people's lives so far. As a wise word suggests the Bugis people in that place "do not take a bath when others are eating". This means how meaningful togetherness is. Being sad or happy has to be done in togetherness. The forms of social interaction among others cover how to do economic competition in a healthy manner together looking for the fulfillment of the needs of life by not ignoring togetherness.

Inter-ethnic interaction is also seen during the Chinese New Year celebration and eid al-fitr. Chinese and Bugis people visit each other. Likewise, in other religious holidays, they always respect each other. The closeness of inter-ethnic relations is not 
only at the formal level but is a reflection from within. Therefore, the intensity of interpersonal relationships in the form of dating or even inter-religious marriages is not unusual in the community.

Religious differences, especially among those who have carried out interethnic marriages, namely Chinese and Bugis are repertoire towards the process of intermingling. Instead, it has started since the meeting of these two ethnicities, since the formation of the Teluk Pak Kedai area around 350 years ago. The various collaborations between the two keep going because of their ability to hold back in a frame of high tolerance. Therefore, it is just usual when there is a good and dynamic relationship until nowadays.

The role of Haji Ismail Mundu in laying the foundations of Islamic social interaction, which contribute modestly to the hearts of Chinese people, then become a role model is not easily dissolved by the issues of economic, social, political competition or even religious belief. It was due to Haji Ismail Mundu has succeeded in laying a solid foundation of friendship for inter-ethnic interaction, in spite of different beliefs (Riyadhi 2011).

Islam that teaches mutual friendship visiting to get to know each other, maintaining unity, loving brothers and sisters in faith, or non-believers, manifests like loving yourself. This belief has been inherent in intermingling Chinese and Bugis ethnicities. Therefore, harmony between ethnic interactions has manifested itself in the daily lives of people (Hermansyah 2014).

Social interaction can be well-realized if each element respects another, is able to hold back on destructive attitudes and puts differences on the basis or valued and respected principles. In other words, the interaction in such region is considered to have entered into the dimensions of human spirit conducted in the dynamics of the social system and of the religious worship 
system. It is not merely a symbol, it is a serious attempt to cultivate religious values in the community for coloring social and religious orders within a civil society instead.

In the Pak Kedai area, the harmony of interaction is not limited to that, the interaction of ethnic Chinese and Bugis people has reached out the level of respecting values of diversity, and it has been continuing to be carried out and permeates in all social aspects that are actualized in inter-ethnic life in spite of the different beliefs. The atmosphere of diversity and social life-also religious-built by the community, is not just a formal social political camouflage because Haji Ismail Mundu indeed laid the foundations and principles of solid social interaction long time ago for the benefit of the life of Teluk Pak Kedai community, Kubu Raya regency, in shaping the modest dynamics of social life (Riyadhi 2011).

\section{Conclusion}

The tradition of the interaction of Chinese (Chinese Hoa precisely) and Malays (Deutro Melayu, precisely Bugis) that developed in the Teluk Pak Kedai reflects a socio-religious harmony. It uniquely portrays two religiosities of Chinese and Bugis; the religiosity (religious) of Chinese, which is theologically and symbiotically open to Bugis religiosity, which is sociologically friendly and dislikes commotion. Both meet together and raise harmony. This symbiotic element was tightly built up by Haji Ismail Mundu, a central figure who was kept "alive" in the hearts of people of the two ethnicities. The harmonious monument is inherent in the phenomena of Tan Boo Kit and Tan Boo Hai. In the first figure, we find an extraordinary mature religious tolerant teaching from Haji Ismail Mundu. This figure adopted Tan Boo Kit's teaching without being eager to convert his adopted child to embrace his religion. On the other hand, the adopted son together with the Chinese people in the region set the teaching of 
tolerance in the name of Tan Boo Kit which means the Bugis person who is surnamed, Tan. The second figure is Tan Boo Hai, a unique healer figure. He treated his patients through the Islamic divine approach. Patients were asked to read the scripture (holy text) of the Quran, even Yasin's book was installed at his door.

Another fascinating dynamics of socio-religious harmony is the absence of ethno-religious prejudice. Inter-ethnic pejorative names are not found in the interaction of Chinese-Malay in the Teluk Pak Kedai. Therefore, no wonder if why the photo of the Haji Ismail Mundu is not only displayed by Malays but also by Chinese (even close to the shrine/Toapekong).

The argument on tolerance between both ethnicities, Chinese-Malay, in the Teluk Pak Kedai converges on the theological underpinning that has been a tradition for a long time. The multiculturalism contextualization applied by Haji Ismail Mundu has strengthened the sociological order in this bay. Let it go is a translation of Mr. Taufiq's story (the fifth generation of Bugis Malays) when he decided to call on the public not to respond, not to communicate and not to open the door for a new element i.e., salafism which was present so that it disappeared by itself by from the region. The Chairperson of the Ngi Hua Ngi Sua Foundation, Mr. Agus, also revealed that the ethnicities worried about such new element, even though it would be brought by grandchildren of people living in the Teluk Pak Kedai.

Pluralism and multiculturalism becoming tradition in the Teluk Pak Kedai can be seen in the presence of parties in the traditional counterpart rituals. Births, marriages, and deaths in Chinese people were attended by Bugis Malays and vice versa. Understanding complemented with obedience to the norms of "tolerance limits" in the context of religion, verbal expression, food, and drink melts in the "sociological wisdom" of the Pak Kedai community. 
For Bugis ethnic groups-also Malays, Arabs, and Madurese-the teachings of Islam are a guide to building friendship with Chinese people, especially in the Teluk Pak Kedai. Visiting to know each other, maintaining unity and love to everyone even though he or she is not in one faith/belief with you, and loving them like loving yourself are among their constructive characteristics in building harmonious relationships in their daily lives. These attitudes of tolerance are based on upholding religious and social values. It shows the causality of inter-ethnic life that requires awareness of each element, and the ability of each ethnic to refrain from all problems for the simplicity of living together.

\section{Bibliography}

Adidharta, Syaifud. 2013. "Etnis China Tionghoa Masih Nomor Satu Kuasai Bisnis Dan Ekonomi Indonesia.” Kompas.

Ali, S. Husin. 1985. Rakyat Melayu Nasib Dan Masa Depannya. Jakarta: Inti Sarana Aksara.

Alqadrie, Syarif Ibrahim. 1987. "Cultural Differences and Social Life among Three Ethnic Groups in West Kalimantan, Indonesia." Agricultural and Rural Sociology, College of Agriculture, University of Kentucky.

- 1990. "Ethnicity and Social Change in Dyanese Society of West Kalimantan, Indonesia." College of Science and Art, University of Kentucky Press.

Arnold, Thomas W. 1995. The Preaching of Islam. Delhi: Low Price Publications.

Brandell, Sir Roland. 1949. "A Note on Sambas and Borneo." Journal of the Malayan Branch of the Royal Asiatic Society 22 (4).

Bruneissen, Martin Van. 1992. Tarekat Naqsabandiyah Di Indonesia: Survai Historis, Geografis Dan Sosiologis. Bandung: Mizan. 
Harvey, Barbara. 1974. "Tradition Islam and Rebellion: South Sulawesi 1950-1965.” Cornel University.

Hermansyah. 2014. Orang Tionghoa Masuk Islam. Pontianak: STAIN Pontianak Press.

Jackson, James C. 1970. Chinese in the West Borneo Goldfields: A Study in Cultural Geography. Hull: University of Hull.

Lyman, Stanford. 1968. "Contrast in the Community Organization of Chinese and Bugis." Universitas Indonesia.

Maksum, Ibnu. 2016. "Ini Dia Strategi China Kuasai Indonesia Melalui Ahok Dan Begundalnya.” suaranasional.com. https://suaranasional.com/2016/07/17/ini-dia-strategi-china-kuasai-indonesia-melalui-ahok-dan-begundalnya/.

Omar. 2017. "8 Alasan Mengapa Reklamasi Teluk Jakarta Harus Dihentikan.” openulis.com. Jakarta. November. https:// www.openulis.com/reklamasi-jakarta/.

Poerwanto, Hari. 2005. Orang Cina Khek Dari Singkawang. Jakarta: Komunitas Bambu.

Purcel, Victor. 1981. The Chinese in Southeast Asia. Kuala Lumpur: Oxford University Press.

Riyadhi, Baidhilah. 2011. Guru H. Ismail Mundu: Ulama Legendaris Kerajaan Kubu. Sei Raya: Dinas Kebudayaan, Pariwisata, Pemuda dan Olahraga.

Suara Jakarta. 2015. "Reklamasi Pantai Jakarta: Pengembang, Gubernur Atau Penjahat Lingkungan?" Jakarta. http:// suarajakarta.co/news/politik/reklamasi-pantai-jakarta-pengembang-gubernur-atau-penjahat-lingkungan/.

Supriyadi, Yohanes. 2008. “Tentang Konflik Di Kalbar.” Pontianak.

Susilo, Richard. 2015. "Peneliti Jepang Ingatkan Indonesia Bisa Berantakan Gara-Gara China.” Tribun News. November. http://www.tribunnews.com/internasional/2015/11/25/ 
CHINESE AND MALAY INTERACTION ...

peneliti-jepang-ingatkan-indonesia-bisa-berantakan-gara-gara-china.

Vasanty, Puspa. 1999. "Kebudayaan Orang Tionghoa Di Indonesia." In Manusia Dan Kebudayaan Di Indonesia. Jakarta: Djambatan. 
This page intentionally left blank 